\title{
The Significance of Professional, Personal and Business Networks to Academic Entrepreneurs
}

\author{
Noorlizawati Abd Rahim ${ }^{1, *}$, Zainai Mohamed ${ }^{2}$, Astuty Amrin $^{2}$, Maslin Masrom $^{1}$ \\ ${ }^{1}$ Department of Science, Management \& Design, Razak Faculty of Technology and Informatics, Universiti Teknologi \\ Malaysia, 54100 Kuala Lumpur, Malaysia \\ 2 Department of Engineering, Razak Faculty of Technology and Informatics, Universiti Teknologi Malaysia, 54100
}

Kuala Lumpur, Malaysia

${ }^{*}$ Corresponding author email: noorlizawati@utm.my

Received date: 10 Dec 2019 Published date: 31 Dec 2019

How to cite:

Abd Rahim, N., Mohamed, Z., Amrin, A. \& Masrom, M. (2019). The Significance of Professional, Personal and Business Networks to Academic

Entrepreneurs. Journal of Research Management \& Governance, 2(1), 1-9. Retrieved from https://ejournal.um.edu.my/ index.php/JRMG/article/ view/21025

DOI:

https://doi.org/10.22452/

jrmg.vol2no1.1

\begin{abstract}
The degree of informational support academic scientists acquired from social network is associated with greater perceived feasibility that may influence their involvement in the research commercialization. Social capital has been commonly assessed by measuring the number of direct contacts from business and industry networks as well as the frequency of establishing new contacts. These approaches, however, have not adequately explained how social capital is beneficial to their entrepreneurial endeavor. This paper attempts to validate social capital as a formative construct using partial least squares structural equation modeling (PLS-SEM) to explore the relative importance of personal, professional and business networks to academic entrepreneurs in their technology transfer pursuit. A sample of 115 academic entrepreneurs of a Malaysian public research university was surveyed. In comparison to early career researchers, it was discovered that academic entrepreneurs among senior researchers benefited more support from their social network. The analyses of formative measurement model to evaluate construct validity, collinearity and significance of indicators revealed that personal network is the most important social resource that facilitate and encourage their technology transfer pursuit, followed with business partners and potential investors. Although scientists have a large professional network through their attendance to conference, workshops and seminars, however, these platforms are often themed to focus more on sharing scientific knowledge rather than on academic entrepreneurship.
\end{abstract}

Keywords: Academic entrepreneurship; formative measurement model; partial least square structural equation modeling; research commercialization; social capital

\section{Introduction}

A large body of literature has focused on the contribution of social capital to the academic entrepreneurship, specifically to the formation of entrepreneurial intention among academic scientists (Landry et al., 2006; Sequeira et al., 2007; Prodan and Drnovsek, 2010; Aldridge and Audretsch, 2011; Goethner et al., 2011; Karlsson and Wigren, 2012; Fernández-Pérez et al., 2015). Indeed, social capital is 
found to be the most important influence among other factors of personal characteristics such as gender and age (Aldridge and Audretsch, 2011). Social capital is made up of contacts to whom an individual relates on a social level (Sequeira et al., 2007; Karlsson and Wigren, 2012). Specifically, social capital is described as, "resources individuals obtain from knowing others, being part of a social network with them, or merely from being known to them" (Baron and Markman, 2000:107). In the academia context, these social networks range from personal, professional and business linkages that the scientists have with other individuals. Friends, close family and colleagues constitute the personal network whom scientists have informal relationships with trusts and shared values. A more formal relationship, professional networks, are established through academic and research activities such as contacts known during attendance to conferences, workshops and seminars. On the other hand, interactions with potential customers, suppliers, investors and competitors constitute networks from the business community.

Different authors have operationalized social capital in a variety of ways. Traditionally, social capital has been assessed by measuring the number of direct contacts from business and industry networks (Renzulli, 2000; Prodan and Drnovsek, 2010; Goethner et al., 2011) as well as the frequency of establishing new contacts (Greve, 1995; Prodan and Drnovsek, 2010; Nielsen et al., 2015). These approaches, however, have not adequately explained how social capital is beneficial to academic scientists in pursuing entrepreneurial endeavour. Notable exceptions are studies that examine specific resources which scientists obtain from social capital such as information and moral support that encourage them to commercialize research discoveries (Sequeira et al. 2007; Obschonka et al. 2011; Fernández-Pérez et al., 2015). Based on the Theory of Planned Behavior, this study postulates that the degree of informational support that scientists acquired from their social network is associated with greater perceived feasibility that may influence their involvement in the technology transfer activities. This study attempts to conceptualize and validate social capital as a formative construct to explore the relative importance of personal, professional and business networks to academic entrepreneurs in their technology transfer pursuit.

\section{Literature Review}

Through social network, scientists benefit both tangible and intangible resources needed in the academic entrepreneurship process. For instance, business network helps to provide information relating to market, new opportunities (Prodan and Drnovsek, 2010) and consumer needs (FernándezPérez et al., 2015), which are useful to scientists as they are generally not business and market-oriented. Indeed, Karlsson and Wigren (2012) asserted that scientists have not traditionally been involved in starting up a business and therefore, having contacts from the business community could facilitate them to pick up the idea and competencies through shared experiences. Furthermore, these business contacts can provide positive referrals that facilitate scientists in getting labor (Karlsson and Wigren, 2012) or funds from venture capitalist (Baron and Markman, 2000). On the other hand, professional networks or contacts from within the academic community allow exchange of ideas and information sharing that benefit the scientists to gain further technical knowledge in their field (Ozgen and Baron, 2007), thus advancing the scientific progress (Kalar and Antoncic, 2015). In facing the challenges of both academic and entrepreneurial endeavour, reliance to close friends and family members for emotional support encourage scientists to keep pursuing their goals (Fernández-Pérez et al., 2015). Apart from enhancing 
access to information, social capital provides scientists the needed technical support, emotional support as well as financial resources.

The importance of social capital exceeds the role of human capital such as years of education, which apparently brought insignificant impact on the propensity of scientist to get involved in the entrepreneurial activity (Ramos-Rodríguez et al., 2010). Consistently, another study on the influence of social capital on the intention to create start-ups among Swedish scientists (Karlsson and Wigren, 2012), made an interesting discovery that scientists' relationship with contacts outside the university established during participation in a product development or contract research actually has an impact on scientists' intention to market their research through business.

In contrast, Prodan and Drnovsek (2010), who compared two European academic settings, found only a partial support to explain a positive relationship between scientists' business network and their entrepreneurial intention to starting a business. Results from their structural equation model indicate a significant and positive path coefficient for University of Ljubljana and a positive but non-significant path coefficient for University of Cambridge. Nonetheless, these results may be affected by cultural determinants and they further suggested for comparison to be made with samples from both developed countries as well as developing countries.

Overall, most of these studies have focused on the impact of social capital towards entrepreneurial intention to create business and there is limited research on the relationship between social capital and scientists' actual engagement in the technology transfer. One notable exception is a recent study by Kalar and Antoncic (2015) to examine scientists from four different European universities regarding their involvement in different types of entrepreneurial activity. Results indicate that scientists' desire to participate in the interdisciplinary projects with industry is stimulated by their social capital. Kalar and Antoncic (2015) also found a positive relationship between such desire and scientists' actual interaction with the industry, which is significantly related to scientists' further engagement in scientific publishing, patenting and creation of start-ups. In terms of comparison between different types of entrepreneurial activities, Audretsch et al. (2006) made an interesting discovery that scientists with strong business networks ended up in licensing activities whereas those who are not active in social networking less likely to patent through TTO and ended up venturing it out through spin-offs.

\section{Methodology}

\subsection{Construct Operationalization}

The construct social capital provides measure on the degree of informational support that scientists acquired from their social network. Fernández-Pérez et al. (2015), who differentiated different kinds of social networks following the works done by Ozgen and Baron (2007), developed 10-items scale to operationalize social capital. They measured social networks from the perspectives of business network (4-items, $\alpha=0.831$ ), professional forums (3-items, $\alpha=0.865$ ) and personal networks (3-items, $\alpha=0.830$ ). These items were modelled as reflective measurement. In contrast, the social capital construct was designed as a formative measurement model in this study because the combination of indicators SC1-5 represent causes to the construct and are not mutually interchangeable (Hair et al., 2014). Respondents 
were asked to rate their agreement or disagreement on the 5-items according to a 6-point Likert scale ranging from (1) strongly disagree to (6) strongly agree.

Table 1: Formative measurement indicators of social capital construct.

\begin{tabular}{|c|c|l|}
\hline Construct & Label & \multicolumn{1}{c|}{ Indicators (Items) } \\
\hline \multirow{5}{*}{ SC1 } & $\begin{array}{l}\text { My contacts from *professional forums have been facilitating } \\
\text { me with information and support that encourage to commer- } \\
\text { cialize research findings }\end{array}$ \\
\cline { 2 - 3 } Social Capital & SC2 & $\begin{array}{l}\text { My contacts from ** personal network have been facilitating } \\
\text { me with information and support that encourage to commer- } \\
\text { cialize research findings }\end{array}$ \\
\cline { 2 - 4 } & SC3 & $\begin{array}{l}\text { My contacts or discussion with potential customers or poten- } \\
\text { tial suppliers have been facilitating me with information and } \\
\text { support that encourage to commercialize research findings }\end{array}$ \\
\cline { 2 - 3 } & SC4 & $\begin{array}{l}\text { My contacts or discussion with new partners or investors have } \\
\text { been facilitating me with information and support that encour- } \\
\text { age to commercialize research findings }\end{array}$ \\
\cline { 2 - 3 } & SC5 & $\begin{array}{l}\text { My contacts or discussion with potential competitors have } \\
\text { been facilitating me with information and support that encour- } \\
\text { age to commercialize research findings }\end{array}$ \\
\hline
\end{tabular}

*professional forums: Conferences/Workshop/Seminars

** personal network: Friends/Close Family/Colleagues

\subsection{Construct Operationalization}

The sample consisted of academic entrepreneurs of one public research university in Malaysia (Universiti Teknologi Malaysia). The size of the target population is 1453. Based on a power analysis (Cohen, 1988; Hair et al., 2014) using G*power software (Faul et al., 2009), the minimum sample size was determined as 92 , with the maximum number of predictors set as five, effect size set as medium (0.15) and power as 0.80 (Gefen et al., 2011). The maximum number of predictors was set as five since there were five dimensions of social capital being assessed. Invitation mails to participate in the survey questionnaire were emailed to the entire list of academic scientists obtained from the official website as well as from the administrative office of engineering and technology departments. Only academic entrepreneurs or scientists who have been involved in the technology transfer pursuit were selected as sample. To ensure a valid response, respondents who scored 'never' to a questionnaire item that enquire if they have developed potential prototype, product, technology or process that can be commercialized by the industry were disregarded. Respondents must first qualify this item (at least answer 'very rarely involved') before their responses as academic entrepreneurs are valid to be considered. Finally, 115 valid questionnaires were received, exceeding the minimum sample size to proceed with data analysis. Table 2 shows the demographic profile of respondents. These respondents were a mixture of $34.8 \%$ Professors, 33\% Associate Professors and 32.2\% Senior Lecturers. In terms of research experiences, $72.2 \%$ of them have more than 10 years' experiences. Only $2.8 \%$ of them have research experiences less than 10 years (early career researchers). 
Table 2: Profile of Respondents.

\begin{tabular}{|c|c|c|}
\hline Variable Name & $\begin{array}{c}\text { Frequency } \\
(n=115)\end{array}$ & $\%$ of sample \\
\hline \multicolumn{3}{|l|}{ Academic Position } \\
\hline Professor & 40 & 34.8 \\
\hline Associate Professor & 38 & 33 \\
\hline Senior Lecturer & 37 & 32.2 \\
\hline Lecturer & 0 & 0 \\
\hline \multicolumn{3}{|l|}{ Faculty } \\
\hline Chemical Engineering & 13 & 11.3 \\
\hline Civil Engineering & 24 & 20.9 \\
\hline Electrical \& Electronic Engineering & 22 & 19.1 \\
\hline Mechanical Engineering & 32 & 27.8 \\
\hline Petroleum Engineering & 0 & 0 \\
\hline Biosciences \& Medical Engineering & 5 & 4.3 \\
\hline Chemistry & 4 & 3.5 \\
\hline Computer Science & 3 & 2.6 \\
\hline Physics & 1 & 0.9 \\
\hline Geo-information \& Real Estate & 9 & 7.8 \\
\hline Others & 2 & 1.7 \\
\hline \multicolumn{3}{|l|}{ Research Experience } \\
\hline Below 10 years & 32 & 2.8 \\
\hline More than 10 years & 83 & 72.2 \\
\hline \multicolumn{3}{|l|}{ Gender } \\
\hline Male & 83 & 72.2 \\
\hline Female & 32 & 27.8 \\
\hline
\end{tabular}

\section{Data Analysis and Results}

An independent sample T-test was conducted to compare between groups of early career researcher and senior researcher on the degree of support these academic entrepreneurs acquired from social network. As shown in Table 3, there is a statistically significant difference ( $t=-3.696, p=0.000$ ) in the scores for early career researcher and senior researcher groups. The magnitude of difference in means is large (effect size $=0.108$ ).

Table 3: Difference in social capital score by categories of academic entrepreneur.

\begin{tabular}{cccc}
\hline & $\begin{array}{c}\text { Early career researcher } \\
\text { (Mean) }\end{array}$ & $\begin{array}{c}\text { Senior researcher } \\
\text { (Mean) }\end{array}$ & t-value \\
\hline $\mathrm{N}$ & 32 & 83 & \\
Social capital & 3.34 & 4.05 & $-3.696^{*}$ \\
\hline$*_{\mathrm{p}}<0.01$ & & &
\end{tabular}


Construct validity, collinearity between indicators and significance/relevancy of indicators were evaluated using SmartPLS 3.0 and IBM SPSS software to validate social capital as a formative construct based on guidelines (Andreev et al., 2009; Lee et al., 2011; Hair et al., 2014; Lowry and Gaskin, 2014). The MTMM (Table 4) shows that the composite scores or indicator-to-construct correlations for SC1(0.263), SC2 (0.960), SC3 (0.625), SC4 (0.731), SC5 (-0.580) were significant at the 0.01 level. All interindicators have significant correlations. These observations met the convergent validity criterion (Loch et al., 2003).

Table 4: Inter-indicator and indicator-to-construct correlation matrix.

\begin{tabular}{cccccc}
\hline & $S C 1$ & $S C 2$ & $S C 3$ & $S C 4$ & $S C 5$ \\
\hline$S C 1$ & & & & & \\
$S C 2$ & $-.444^{* *}$ & & & & \\
$S C 3$ & $-.419^{* *}$ & $.624^{* *}$ & & & \\
$S C 4$ & $-.293^{* *}$ & $.590^{* *}$ & $.557^{* *}$ & & \\
SC5 & $.284^{* *}$ & $-.542^{* *}$ & $-.544^{*}$ & $-.599^{* *}$ & \\
SC_CS & $-.263^{* *}$ & $.960^{* *}$ & $.625^{* *}$ & $.731^{* *}$ & $-.580^{* *}$ \\
\hline
\end{tabular}

(SC1, SC2, SC3, SC4, SC5 Indicators' weighted scores; SC_CS Composite scores for social capital construct) $p<0.01$

The collinearity statistics (Table 5) show that the variance inflation factors (VIF) for all the indicators were below 3.3, indicating the absence of collinearity (Diamontopoulos and Siguaw, 2006). Since the VIF check confirmed no critical levels of collinearity, the formative measurement model for social capital construct was adequately validated without the need to remove any indicators to proceed with interpretation of relative contribution of each formative indicator (Hair et al., 2014).

Table 5: Collinearity statistics for social capital construct.

\begin{tabular}{ccc}
\hline \multirow{2}{*}{ Indicators } & \multicolumn{2}{c}{ Collinearity Statistics } \\
\cline { 2 - 3 } & Tolerance & VIF \\
\hline SC1 & 0.77 & 1.30 \\
SC2 & 0.48 & 2.09 \\
SC3 & 0.51 & 1.96 \\
SC4 & 0.52 & 1.92 \\
SC5 & 0.56 & 1.79 \\
\hline
\end{tabular}

The outer weight and loading significance testing results are shown in Table 6. Two indicators SC3 and SC5 did not have significant outer weights but their outer loadings were above 0.5 and significant. The outer weights were the results of multiple regression between indicators and the construct with coefficient of determination (R2) value of 1.0. This implies that the indicators explain $100 \%$ of the construct and thus the outer weights can be compared to determine their relative contribution to the construct. The relative effect of each indicator was interpreted based on the guidelines by Cenfetelli and Bassellier (2009). Significant indicators with positive weights (SC2 and SC4) were compared based on their magnitudes. On the other hand, since the outer weights for SC3 and SC5 were not significant, their 
effects cannot be compared with the other indicators within the same construct. Significant indicator with negative weight like SC1 (professional forums) was interpreted as having negative effect when the effects of other indicators within the same construct are controlled. Therefore, the results showed the relative effect of indicators towards social capital construct is given by personal network (SC2=0.897) as the strongest, followed by new partners and potential investors (SC4=0.261).

Table 6: Outer weight and loading significance testing results.

\begin{tabular}{cccc}
\hline Construct & Indicators & $\begin{array}{c}\text { Outer } \\
\text { Weights }\end{array}$ & $\begin{array}{c}\text { Outer } \\
\text { Loading }\end{array}$ \\
\hline \multirow{5}{*}{ Social capital } & SC1 & $-0.216^{*}$ & $0.263^{* *}$ \\
& SC2 & $0.897^{* *}$ & $0.960^{* *}$ \\
& SC3 & 0.016 & $0.625^{* *}$ \\
& SC4 & $0.261^{*}$ & $0.731^{* *}$ \\
& SC5 & -0.009 & $0.580^{* *}$ \\
\hline
\end{tabular}

$* \mathrm{p}<0.05(\mathrm{t}>1.645),{ }^{*} \mathrm{p}<0.01(\mathrm{t}>2.33)$

\section{Conclusions}

This paper attempts to conceptualize and validate social capital as a formative construct to explore the relative importance of personal, professional and business networks to academic entrepreneurs in their technology transfer pursuit to complement the literature in explaining how social capital is beneficial to academic scientists in pursuing entrepreneurial endeavor. In comparison to early career researchers, it was observed that academic entrepreneurs among senior researchers benefit more support from their social network. The analysis of formative measurement model revealed that personal network, which is made up of close family and friends is the most important social resources that facilitate and encourage their technology transfer pursuit. The second most important social resources are obtained from contacts that they have with business partners and potential investors. These observations are consistent with the earlier findings (Sequeira et al., 2007) that a supportive and strong relationship with personal network brings a stronger effect to the formation of entrepreneurial intention than the effect of relationship with non-affective contact like business networks.

Interestingly, a significant inverse relationship was found for the effect of scientists' professional network to their involvement in the technology transfer activities, which is in accordance with the earlier findings by Fernández-Pérez et al., (2015). In general, scientists are likely to have a large number of contacts from professional network through their attendance to conference, workshops and seminars, which supposed to relate closely to their task as academician. However, these conferences, workshops and seminars are often themed to focus more on sharing scientific knowledge rather than on academic entrepreneurship. Therefore, the inverse relationship results in this study is justifiable by the fact that knowledge sharing platforms that are specifically themed on academic entrepreneurship or how opportunities could be exploited from academic research are still not widely practiced in the academia. This outcome is contrary to that Aldridge and Audretsch (2011), who found that scientists with higher levels of social capital from the professional network, specifically if they have co-authored articles with 
another scientists that are working with a company, are more likely to get involved in the technology transfer activities.

\section{References:}

Aldridge, T.T. \& Audretsch, D. (2011). The Bayh-Dole Act and Scientist Entrepreneurship. Research Policy, 40(8), 1058-1067.

Andreev, P., Heart, T., Maoz, H. \& Pliskin, N. (2009). Validating Formative Partial Least Squares (PLS) Models: Methodological Review and Empirical Illustration. Proceedings of the International Conference on Information System, December 15-18, 2009, Phoenix, USA. Phoenix, USA: AIS Electronic Library.

Audretsch, D.B. (2007). The Entrepreneurial Society. Oxford: University Press.

Baron, R.A. \& Markman, G.D. (2000). Beyond Social Capital: How Social Skills Can Enhance Entrepreneurs' Success. The Academy of Management Executive, 14(1), 106-116.

Cenfetelli, R.T. \& Bassellier, G. (2009). Interpretation of formative measurement in information systems research. MIS Quarterly, 33, 689-707.

Cohen, J. (1988). Statistical Power Analysis for the Behavioral Sciences. London: Lawrence Erlbaum Assoc.

Diamantopoulos, A. \& Siguaw, J.A. (2006). Formative versus reflective indicators in organizational measure development: A comparison and empirical illustration. British Journal of Management, 17 (4), 263-282.

Faul, F., Erdfelder, E., Buchner, A. \& Lang, A.G. (2009). Statistical Power Analyses Using G* Power 3.1: Tests for Correlation and Regression Analyses. Behavior Research Methods, 41(4), 1149-1160.

Fernández-Pérez, V., Alonso-Galicia, P.E., Rodríquez-Ariza, L. \& del Mar Fuentes-Fuentes, M. (2015). Professional and Personal Social Networks: A Bridge to Entrepreneurship for Academics? European Management Journal, 33(1), 37-47.

Gefen, D., Straub, D.W. \& Rigdon, E.E. (2011). An Update and Extension to SEM Guidelines for Administrative and Social Science Research. Management Information Systems Quarterly, 35(2), 314.

Goethner, M., Obschonka, M., Silbereisen, R.K. \& Cantner, U. (2011). Foundations of Academic Entrepreneurship: A Path Model for the Prediction of Scientists' Academic Entrepreneurial Intentions. DIME Final Conference. April 6-8, 2011. Maastricht, Netherlands. Maastricht, Netherlands: Maastricht University.

Greve, A. (1995). Networks and Entrepreneurship: An Analysis of Social Relations, Occupational Background and Use of Contacts during the Establishment Process. Scandinavian Journal of Management, 11(1), 1-24.

Hair, J.F., Hult, G.T.M., Ringle, C. \& Sarstedt, M. (2014). A Primer on Partial Least Squares Structural Equation Modeling (PLS-SEM). US: Sage Publications.

Kalar, B. \& Antoncic, B. (2015). Social Capital of Academics and Their Engagement in Technology and Knowledge Transfer. Science and Public Policy, 43(5), 646-659.

Karlsson, T. \& Wigren, C. (2012). Start-ups among University Employees: The Influence of Legitimacy, Human Capital and Social Capital. The Journal of Technology Transfer, 37(3), 297-312.

Landry, R., Amara, N. \& Rherrad, I. (2006). Why Are Some University Researchers More Likely to Create Spin-offs Than Others? Evidence from Canadian Universities. Research Policy, 35(10), 1599-1615.

Lee, L., Petter, S., Fayard, D. \& Robinson, S. (2011). On The Use Of Partial Least Squares Path Modeling In Accounting Research. International Journal of Accounting Information Systems, 12(4), 305-328.

Loch, K.D., Straub, D.W. \& Kamel, S. (2003). Diffusing the Internet in the Arab World: The Role of Social Norms and Technological Culturation. IEEE Transactions on Engineering Management, 50(1), 45-63.

Lowry, P.B. \& Gaskin, J. (2014). Partial Least Squares (PLS) Structural Equation Modeling (SEM) for 
Building and Testing Behavioral Causal Theory: When To Choose It and How to Use It. IEEE Transactions on Professional Communication, 57(2), 123-146.

Nielsen, K. (2015). Human Capital and New Venture Performance: The Industry Choice and Performance of Academic Entrepreneurs. The Journal of Technology Transfer, 40(3), 453-474.

Obschonka, M., Silbereisen, R.K., Schmitt-Rodermund, E. \& Stuetzer, M. (2011). Nascent Entrepreneurship and the Developing Individual: Early Entrepreneurial Competence in Adolescence and Venture Creation Success during the Career. Journal of Vocational Behavior, 79(1), 121-133.

Ozgen, E. \& Baron, R. A. (2007). Social Sources of Information in Opportunity Recognition: Effects of Mentors, Industry Networks, and Professional Forums. Journal of Business Venturing, 22(2), 174192.

Prodan, I. \& Drnovsek, M. (2010). Conceptualizing Academic-Entrepreneurial Intentions: An Empirical Test. Technovation, 30(5-6), 332-347.

Ramos-Rodríguez, A., Medina-Garrido, J., Lorenzo-Gómez, J. \& Ruiz-Navarro, J. (2010). What You Know or Who You Know? The Role of Intellectual and Social Capital in Opportunity Recognition. International Small Business Journal, 28(6), 566-582.

Renzulli, L.A., Aldrich, H. \& Moody, J. (2000). Family Matters: Gender, Networks and Entrepreneurial Outcomes. Social Forces, 79(2), 523-546.

Sequeira, J., Mueller, S.L. \& McGee, J. E. (2007). The Influence of Social Ties and Self-Efficacy in Forming Entrepreneurial Intentions and Motivating Nascent Behaviour. Journal of Developmental Entrepreneurship, 12(3), 275-293. 